\title{
Recommended Hints for Improved Lifestyle and Health from Integrative Medicine (IM) In the Critical Situation of COVID-19
}

Bando $\mathrm{H}^{1,2^{*}}$

${ }^{1}$ Medical Research/Tokushima University, Tokushima, Japan

${ }^{2}$ Director, Shikoku Division of Integrative Medicine Japan (IMJ), Japan

Corresponding Author: Hiroshi BANDO, MD. PhD, FACP ${ }^{\text {ORCID ID }}$

Address: Medical Research/Tokushima University, Nakashowa 1-61, Tokushima 770-0943, Japan; Tel: +81-90-31872485; Fax: +81-88-6o3-1030; E-mail: pianomed@bronze.ocn.ne.jp

Received date: 30 April 2020; Accepted date: 16 May 2020; Published date: 21 May 2020

Citation: Bando H. Recommended Hints for Improved Lifestyle and Health from Integrative Medicine (IM) In the Critical Situation of COVID-19. Diab Res Open Access. 2020 May 21;2(2):17-21.

Copyright (C) 2020 Bando H. This is an open-access article distributed under the Creative Commons Attribution License, which permits unrestricted use, distribution, and reproduction in any medium, provided the original work is properly cited.

\begin{abstract}
For the current critical situation of COVID-19 worldwide, several recommended hints for improved lifestyle and health were described from integrative medicine (IM) point of view. It includes some categories as follows. i) Exercise: Hippocrates said that walking is the best medicine. Walking fast, climbing stairs, and squats are effective. ii) Sleep and rhythmic lifestyle: Keep sleep and wake up time regularly, avoid looking at display or VDT work before sleep, and have bright light when waking up, especially sunlight. iii) Mental care: The US CDC presents the stressful influences, such as fear and worry about health, worsening of chronic health problems, and increased use of alcohol. Some recommendations of controlling heart and minds include keeping the natural feeling of being as it is, and mindfulness related to the oriental Zen concept. iv) Nutrition: IM and antiinflammatory diet were proposed by Dr. Andrew Weil at Arizona University. The diet is based on two diets-the Mediterranean diet and the Okinawan diet. v) IM: Several applicable tips for IM show chiropractic, aromatherapy, supplements, medical herbs, Chinese medicine, Ayurveda, acupuncture, and others.
\end{abstract}

\section{Keywords}

COVID-19, Integrative Medicine, New Elderly Association, Integrative Medicine Japan, Mindfulness, Antiinflammatory Diet

\begin{abstract}
Abbreviations Medicine Japan

Across the world, the pandemic of COVID-19 has been developed [1]. A variety of organizations worldwide have continued maximum efforts to manage this critical issue $[2,3]$.
\end{abstract}

COVID-19: Coronavirus Disease 2019, IM: Integrative Medicine, NEA: New Elderly Association, IMJ: Integrative

In Asploro open access publications, each editorial committee has been also anxious about the matter and considering for medical papers. When editorial committees receive any report concerning COVID-19, we review it immediately and present the paper on the internet site as soon as possible with totally no APC $[4,5]$. Due to this situation, many people in the world 
Citation: Bando H. Recommended Hints for Improved Lifestyle and Health from Integrative Medicine (IM) In the Critical Situation of COVID-19. Diab Res Open Access. 2020 May 21;2(2):17-21.

Short Communication

have been obliged to stay home and keep still. Then, it is rather difficult to maintain and improve health.

On the other hand, the author has continued various research concerning integrative medicine (IM) [6], psychosomatic medicine, music therapy, diabetes, low carbohydrate diet (LCD) [7], sports medicine [8], and so on. Furthermore, we have developed the movement of Japan LCD promotion association (JLCDPA), New Elderly Association (NEA) of Hinoharaism, and Shikoku Island of Integrative Medicine Japan (IMJ) [9]. Combined with these situations above, how to continue self-care in current daily life with COID-19 would be important. It includes some categories, such as 1) exercise, 2) sleep and rhythmic lifestyle, 3) mental care, 4) nutrition and 5) IM. Their topics for daily life are described in this article.

\section{Exercise:}

"Walking is the best medicine," said Hippocrates, the father of medicine [10]. Conventionally, the use of aerobic exercise and anaerobic exercise (muscle training) has been widely known. A cytokine related to exercise has been myokine [11]. This is a generic term for the cytokine group that transmits intercellular information secreted from moving a skeletal muscle. The example of myokine is interleukin-6 (IL-6) [12]. IL-6 has been thought as an inflammatory protein in some inflammatory situations. However, during exercise, IL-6 secreted by skeletal muscle has been evaluated to be a preferable factor, which would regulate the body [13].

Myokine can increase with light exercise, so walking fast or climbing stairs is sufficient for the stimulation. In particular, myokine is secreted mainly from the lower half the body, then $10 \times 3$ squats plus walking (100oo steps per day) daily may be easy and effective.

The author has been investigating the exercise situation and lifestyle of Masters athletes. Among them, the ice-skating athletes of the Masters were characterized by low blood TG levels in blood lipids due to continued aerobic exercise for long years [14]. Therefore, it will lead to the prevention of lifestylerelated diseases and metabolic syndrome.

\section{Sleep and regular rhythm lifestyle:}

It is said that $20 \%$ of modern people have sleep disorders. Reasons for this include stressful life, irregular lifestyles, living with not sunlight but artificial light, influences of VDT (Visual Display Terminals) devices, and work that does not use muscles.

The reasons why sleep is important are: i) sleep adjusts the body and brain, ii) keeps and strengthens necessary memories, and iii) collects the necessary information for a person to live during sleep. The quality of sleep is involved in the various patterns of Rapid Eye Movement (REM) sleep and non-REM sleep [15].

This sleep unit with an average period of about 90 minutes is repeated 4 to 5 times overnight. The parasympathetic nerve becomes dominant during nonREM sleep. It is time to give the body relaxes, sleep, and recover. Our body has a circadian clock mechanism to respond to daily rhythms and seasonal changes. When we are exposed to the light in the morning, the function in the brain is reset, and the body can wake up for active life [16].

There are several recommended points for getting good sleep. They are i) sleep 7 hours from 11:00 pm to 6:0o am the next day, ii) keep sleep and wake up time regularly, iii) make your bedroom dark and free of blinking lights, iv) have bright light when waking up, especially sunlight, v) dinner should not be skipped, but finished at least 1 hour before bedtime, vi) avoid caffeine and alcohol too much, vii) avoid looking at the display or VDT work before sleep, viii) Read a relaxing book or listen to quiet music before bed.

\section{Mental Care:}

The US CDC said on the homepage that the COVID19 outbreak was stressful with the following influences [17]. They are i) Fear and worry about your health and the health of your loved ones, ii) Changes in sleep or eating patterns, iii) Difficulty sleeping or concentrating iv) Worsening of chronic health problems, v) Worsening of mental health conditions, vi) Increased use of alcohol, tobacco or other drugs. 
Citation: Bando H. Recommended Hints for Improved Lifestyle and Health from Integrative Medicine (IM) In the Critical Situation of COVID-19. Diab Res Open Access. 2020 May 21;2(2):17-21.

\section{Short Communication}

There is Canada's largest mental health teaching hospital (CAMH), which has set the standards for care, research, education, and leading social change [18]. They have various challenges on individuals and families which respond to the demands of the difficult situation. The site is to give information and suggestions about how best to cope with this matter.

In the field of IM, Andrew Weil Center for IM at the University of Arizona has presented the information on the internet [19]. There are many ways to support our immune system, to help reduction of the risk and to reduce the severity or duration of infection [19].

From the combination of oriental and western philosophy, the author recommends the following tips for controlling our heart and minds.

1) We value the natural feeling of being as it is. You can cry and talk about painful matters.

2) Do not try too hard. Depending on the situation, you can put in and put out force.

3) The ideal level is impossible. Initiate from what is possible in limited circumstances.

4) The target is low at the beginning. Gradually increase as you go up the stairs.

\begin{tabular}{|c|c|c|c|c|c|}
\hline \multicolumn{6}{|c|}{ Table-1: Recommended self-care by Integrative Medicine (IM) } \\
\hline CAM & Exercise & $\begin{array}{c}\text { Sleep and } \\
\text { Rhythmic Life } \\
\text { Style } \\
\end{array}$ & Mental Care & Nutrition & Others \\
\hline Chiropractic & $\begin{array}{l}\text { 1) Regular exercise, } \\
\text { walking } 15-30 \text { min, } \\
\text { stretch, weight } \\
\text { training; } \\
\text { 2) Remote working, } \\
\text { stretch of neck, } \\
\text { shoulder; } \\
\text { 3) relax/work 5omin }\end{array}$ & $\begin{array}{l}\text { 1) Recommendation } \\
\text { of fast sleep for } \\
\text { enough hours in the } \\
\text { bed room; } \\
\text { 2) Refrain } \\
\text { insufficient sleep on } \\
\text { the couch, sofa or } \\
\text { chair }\end{array}$ & None & None & None \\
\hline Aromatherapy & None & $\begin{array}{l}\text { Lavender is } \\
\text { recommended } \\
\text { 1) use diffuser in } \\
\text { bed room; } \\
\text { 2) before sleep, } \\
\text { taking a bath; } \\
\text { 3) add elements in } \\
\text { bath salt; } \\
\text { 4) apply carrier oil } \\
\text { to the chest; } \\
\text { 5) Chamomile tea }\end{array}$ & $\begin{array}{l}\text { Change the mood } \\
\text { by the essential } \\
\text { oils } \\
\text { 1) relax, reduce } \\
\text { tension; } \\
\text { 2) choice as one } \\
\text { likes; } \\
\text { 3) lavender, } \\
\text { orange, mandarin, } \\
\text { ylang-ylang }\end{array}$ & None & $\begin{array}{l}\text { Essential oils } \\
\text { with possible } \\
\text { antiviral } \\
\text { effects by tea } \\
\text { tree and } \\
\text { eucalyptus } \\
\text { radiata. }\end{array}$ \\
\hline Supplements & None & None & None & $\begin{array}{l}\text { Possible effects } \\
\text { exist for } \\
\text { reducing the risk } \\
\text { of infection. } \\
\text { 1) vitamin C: } \\
\text { 10oo- } \\
\text { 20oomg/day; } \\
\text { 2) vitamin D: } \\
\text { 10oo IU/day } \\
\text { 3) Zinc: } 13-20 \\
\text { mg/day }\end{array}$ & $\begin{array}{l}\text { Zinc } \\
\text { supplement } \\
\text { for a few days } \\
\text { may shorten } \\
\text { morbidity } \\
\text { period of the } \\
\text { symptoms. }\end{array}$ \\
\hline
\end{tabular}


Citation: Bando H. Recommended Hints for Improved Lifestyle and Health from Integrative Medicine (IM) In the Critical Situation of COVID-19. Diab Res Open Access. 2020 May 21;2(2):17-21.

Short Communication

5) Individuals are different. Find the best way to keep your body and mind healthy.

\section{Nutrition:}

IM and anti-inflammatory diet were proposed by Dr. Andrew Weil at Arizona University [22]. The University of Arizona Center for Integrative Medicine (AzCIM) was founded in 1994 with a primary focus of educating physicians in IM. Twenty years later, IM has become an internationally recognized movement in medicine [22].

The anti-inflammatory diet is based on two dietsthe Mediterranean diet and the Okinawan diet [23]. The anti-inflammatory diet is more than just a prescription for healthy food, but rather a way of life characterized by a plant-based diet. It includes eating various locally grown seasonal foods, culinary activities, physical activity, and rest [23].

\section{Integrative Medicine (IM):}

For the current social and medical situation, it will be possible for each person to apply various kinds of integrative medical care available at home. These mechanisms include i) warm the body, ii) increase blood flow, iii) stimulate the endocrine and immune system and iv) improve the natural healing power. Examples include chiropractic, aromatherapy, supplements, medical herbs, Chinese medicine [24], Ayurveda, acupuncture, and others. Table-1 shows the easy-to-use items.

In summary, the information useful for people to self-care at home was introduced in this article. Hopefully, these tips would help to prevent infectious diseases and to maintain and progress daily health in the world.

\section{References}

[1] Yan Y, Shin WI, Pang YX, Meng Y, Lai J, You C, Zhao H, Lester E, Wu T, Pang CH. The First 75 Days of Novel Coronavirus (SARS-CoV-2) Outbreak: Recent Advances, Prevention, and Treatment. Int J Environ Res Public Health. 2020 Mar 30;17(7). pii: E2323. [PMID: 32235575]

[2] World Health Organization (WHO). Available from: https://www.who.int/docs/defaultsource/coronaviruse/

[3] Centers for Disease Control and Prevention (CDC). Available from:

https://www.cdc.gov/coronavirus/2019-ncov/

[4] Stephen P. How Can We Develop Immunity against COVID-19 and Defeat It. Diab Res Open Access. 2020 Apr 16;2(1):9-11.

[5] Hussain YH, Baderkhan B, Hamid M, Hamid A. Mortalities and Morbidities Trends of COVID-19 Infection, From Explosiveness to Aggressiveness, Understanding Gaps in System Response and Transmission Chain Events. J Health Care and Research. 2020 Apr 01;1(1):22-27.

[6] Bando H, Yoshioka A, Nishikiori Y. (2020) Various Care Option of Integrative Medicine from the Viewpoint of Patient-Oriented Medicine. Int J Conf Proc. 2020;2(1).

[7] Ebe K, Bando H, Muneta T, Bando M, Yonei Y. Useful Measurement of Glucose Variability by Flash Glucose Monitoring (FGM) with the Efficacy of Sodium-Glucose Cotransporter 2 (SGLT2) Inhibitor. Diab Res Open Access. 2020 Jan 06;2(S1):1-8.

[8] Murakami M, Bando H, Moriyasu A. Various Human Movements can be compared to the Concept of Three Spherical Surfaces as Head, Lung and Pelvis. Jour Orthop Re There: JORT. 2020;105.

[9] Bando H. Fundamental Philosophy of Health and Medical Care would be Hinoharaism. J Health Care and Research. 2019 Nov 20;1(1):1-3.

[10] Batman DC. Hippocrates: 'Walking is man's best medicine!'. Occup Med (Lond). 2012 Jul;62(5):320-22. [PMID: 22764266]

[11] Hoffmann C, Weigert C. Skeletal Muscle as an Endocrine Organ: The Role of Myokines in Exercise Adaptations. Cold Spring Harb Perspect Med. 2017 Nov 1;7(11). pii: ao29793. [PMID: 28389517]

[12] Pal M, Febbraio MA, Whitham M. From cytokine to myokine: the emerging role of interleukin- 6 in metabolic regulation. Immunol Cell Biol. 2014 Apr;92(4):331-39. [PMID: 24751614]

[13] Kaniganti US, Majumdar P. Effect of a weight lifting training session on leukocyte count and myokine (Interleukin-6) levels. J Phys Educat Sport. 2019 Dec 1;19(4):2435-40.

[14] Bando H, Nakamura T, Yonei Y, Takenaka Y, Seki

K. Lipid profile of masters athletes in ice-skating, a 
Citation: Bando H. Recommended Hints for Improved Lifestyle and Health from Integrative Medicine (IM) In the Critical Situation of COVID-19. Diab Res Open Access. 2020 May 21;2(2):17-21.

Short Communication

model of anti-aging research. Glycative stress research. 2015 Jun 30;2(2):52-57.

[15] Stevner ABA, Vidaurre D, Cabral J, Rapuano K, Nielsen SFV, Tagliazucchi E, Laufs H, Vuust P, Deco G, Woolrich MW, Van Someren E, Kringelbach ML. Discovery of key whole-brain transitions and dynamics during human wakefulness and non-REM sleep. Nat Commun. 2019 Mar 4;10(1):1035. [PMID: 3083356o] [16] Ashbrook LH, Krystal AD, Fu YH, Ptáček LJ. Genetics of the human circadian clock and sleep homeostat. Neuropsychopharmacology. 2020

Jan;45(1):45-54. [PMID: 31400754]

[17] US CDC comment. Available from:

https://www.cdc.gov/coronavirus/2019-ncov/daily-

life-coping/managing-stress-anxiety.html

[18] CAMH comment for COVID-19. Available from: https://www.camh.ca/en/health-info/mental-healthand-covid-19

[19] Andrew Weil Center for Integrative Medicine. Arizona University. Available from:

https://integrativemedicine.arizona.edu/covid_19.html
[20] Bamber MD, Morpeth E. Effects of mindfulness meditation on college student anxiety: A meta-analysis. Mindfulness. 2019 Feb 1;10(2):203-14.

[21] Hazlett-Stevens H. Zen, Mindfulness, and Cognitive-Behavior Therapy. In Handbook of Zen, Mindfulness, and Behavioral Health 2017 (pp. 255270). Springer, Cham.

[22] Maizes V, Horwitz R, Lebensohn P, McClafferty H, Dalen J, Weil A. The evolution of integrative medical education: the influence of the University of Arizona Center for Integrative Medicine. J Integr Med. 2015 Nov;13(6):356-62. [PMID: 2655936o]

[23] Mascarenhas MR. Pediatric Anti-Inflammatory Diet. Pediatr Ann. 2019 Jun 1;48(6):e220-e225. [PMID: 31185112]

[24] Yang Y, Islam MS, Wang J, Li Y, Chen X. Traditional Chinese Medicine in the Treatment of Patients Infected with 2019-New Coronavirus (SARSCoV-2): A Review and Perspective. Int J Biol Sci. 2020 Mar 15;16(10):1708-17. [PMID: 32226288]

Keywords: COVID-19, Integrative Medicine, New Elderly Association, Integrative Medicine Japan, Mindfulness, Antiinflammatory Diet 